\title{
Yeni Medya ile Yeni Gazetecilik Anlayışı: Haber Ajanslarının Sosyal Medya Gazeteciliği Açısından İncelenmesi
}

\author{
Aylin Tutgun-Ünal (Dr. Öğr. Üyesi) \\ Üsküdar Üniversitesi Iletişim Fakültesi \\ aylin.tutgununal@uskudar.edu.tr \\ Başvuru Tarihi: 14.11.2019 \\ Yayına Kabul Tarihi: 10.06.2020 \\ Yayınlanma Tarihi: 24.07.2020 \\ https://doi.org/10.17680/erciyesiletisim.647078 \\ Öz
}

Günümüzde haber almak için ilk başvurulan kaynağın sosyal medya olması ile vatandaşların, haber ajanslarının, politikacıların ve pek çok meslek alanındaki profesyonel kişilerin sıklıkla sosyal medya hesaplarından haber yayını yapması gazeteciliği farklı bir boyuta taşımıştır. Önceleri internet gazeteciliği için bahsedilen pek çok avantajlı özelliğin şimdilerde sosyal medya platformlarına taşınması ve sosyal ağların kendine özgü doğasıyla birleşmesi sonucunda sosyal medya gazeteciliği kavramı tartışılmaya başlamıştır. Böylece haber kuruluşlarının sosyal medya ölçümleme sitelerine kaydolarak performans takibi yapmaları ve sosyal medya hesaplarından günlük haberleri paylaşmaları yeni bir gazetecilik alanının ve çalıșma şeklinin doğacağının sinyalini vermiștir. Twitter gazeteciliği, Instagram gazeteciliği, YouTube gazeteciliği ve hatta hikâye gazeteciliği gibi sosyal medya gazetecilik türlerinin toplumun haber alma ihtiyacını karşılamada yeni bir alan yarattığı görülmektedir. Bu araştırmada ülkemizde popülerliği ile bilinen üç haber ajansının sosyal medya gazeteciliği yönünden incelenmesi amaçlanmıştır. Genel tarama modeline göre yürütülen araştırmada, üç haber ajansının Facebook, Instagram, Twitter ve YouTube hesaplarındaki takipçi sayıları, haber paylaşım sıklıkları, takipçi artış oranları ve paylaştıkları ileti türleri incelenerek sosyal medya gazeteciliği açısından karşılaştırılmıştır. Böylece haber ajanslarının yeni gazetecilik anlayışına yönelik tutumlarının ileriye dönük yapacakları çalışmalara yön vereceği düşünülmektedir.

Anahtar Kelimeler: Gazetecilik, Yeni Medya, Sosyal Medya, Sosyal Medya Gazeteciliği. 


\title{
New Journalism Approach via New Media: Analysis of News Agencies in terms of Social Media Journalism
}

\author{
Aylin Tutgun-Ünal (Asst. Prof. Dr.) \\ Üsküdar University Faculty of Communication \\ aylin.tutgununal@uskudar.edu.tr
}

Date Received: 14.11.2019

Date Accepted: 10.06 .2020

Date Published: 24.07.2020

https://doi.org/10.17680/erciyesiletisim.647078

\begin{abstract}
Today, social media has become the number one news source; therefore, citizen journalists, news agencies, politicians, and various professionals often share news on their social media accounts, which changed journalism's face. Many advantageous features previously associated with internet journalism can be found on social media nowadays. With the inherent connectivity of social platforms, social media journalism started to be debated as a concept. Thus, news agencies enrolled in social media measurement sites to track their performance and started to share daily news on their social media accounts, which heralded a new era of journalism and new ways of operating. New types of social media journalism such as Twitter journalism, Instagram journalism, YouTube journalism, and more specifically, Story journalism meets the needs of the online social media society for information and create new venues that are predicted to expand soon. This study aims to investigate three news agencies which are known for their popularity in Turkey, in terms of social media journalism. In the research carried out according to the general survey model, the number of followers on Facebook, Instagram, Twitter and YouTube accounts, news sharing frequency, weekly follower growth rates, and the types of shared messages of three news agencies were examined and compared in terms of social media journalism. Thus, it is believed that news agencies' attitudes towards the new journalism approach will guide future studies.
\end{abstract}

Keywords: Journalism, New Media, Social Media, Social Media Journalism. 


\section{Giriş}

Yeni çağda mobil teknolojilerin hayatımızda olmazsa olmaz bir yer almasıyla pek çok iş yapma şekli ve iletişim alıșkanlıkları değișip dönüșmüștür. Mobil teknolojileri sunduğu internet imkânı ile küresel çapta iletişim kurma imkânı sağlarken, aynı zamanda da sınırsız enformasyon yayılımına maruz kalınmaktadır. Türkiye İstatistik Kurumu'nun düzenli olarak yürüttügü teknoloji kullanım araștırmalarında hanelerde teknoloji kullanımının geçmişten bugüne giderek artış göstermesi ve 2017 yılında akıllı telefon bulunan ev oranının yüzde 97,8 olarak bildirilmesi mobil telefonların hayatımızın vazgeçilmez bir parçası olduğunu gözler önüne sermektedir.

Web 2.0 teknolojileri ile ortaya çıkan sosyal medya ağları özellikle mobil telefonlara kurulan uygulamalar ile erişim sağlanarak her yaştan bireyin katılımıyla yoğun kullanılmaktadır. Başlangıçta sosyalleşme, haberleşme, eğlence, eğitim gibi pek çok amaçla kullanılan sosyal medya ağlarının şimdilerde beğeni alışverişi, takip edeni takip etme gibi konularla daha çok kişilerarası ilişkilerdeki fonksiyonelliği ile ön plana çıkması bu ağların pek çok alanda kişileri etkileyici gücünün sorgulanmasına ve kişilik özelliklerini belirlemede ne şekilde kullanılabileceğinin araştırılmasına sebep olmuştur (Özdemir, 2017; Tarhan, 2019; Tutgun-Ünal, 2019a, 2020a).

Sosyal ağların bireyi ve toplumu etkileyici gücü sosyal medyada topluluk oluşturarak sesini duyurmak isteyen herkesin ilgisini çekmekte olup sosyal medya yönetimi yapan profesyoneller ile bireylerin kullanımıyla mozaik yapıların oluşumuna sebep olmuştur. Akyazı ve Tutgun-Ünal'a (2013, s. 3) göre günümüzde baskın olan kültür katılımcı kültürdür ve günümüzde en yaygın örneği sosyal medya ağlarında görülmektedir. Böylece, sosyal medya ağlarında katılımcı kültürde olduğu gibi kullanıcıların ne söylediği, birbiri hakkında ne düşündüğü önemli olduğundan kullanıcıların fotoğraf, video, metin, konum, duygu durumu gibi pek çok içeriği üretip paylaştıkları ve paylaşılan içeriklerin ne derece kabul gördüğü, kişilerin görüşleri veya beğenileri önemsenmektedir.

Sosyal medya ağları iletişim, eğitim, bilişim, psikoloji gibi pek çok alanda araştırma konusu olmaktadır (Akyazı ve Tutgun-Ünal, 2013; Kıyan ve Törenli, 2018; Özdemir, 2017; Tutgun-Ünal ve Deniz, 2019; Tutgun-Ünal ve Katmer-Bayraklı, 2014). Şimdilerde habercilikte gelinen noktada da internet haberciliğinin sosyal medya haberciliğine kayması ve özellikle de görselliği ile ön plana çıkan Instagram uygulamasından hikâye haberciliği yapılması araştırmaların da sosyal medya gazeteciliğine evrileceğini göstermektedir (Tutgun-Ünal, 2019b, 2020b).

Son zamanlarda vatandaşların söylediklerinin birinci ağızdan enformasyon değeri taşıması artık merak edilen bir konuda sosyal medya hesaplarının kontrol edilmesine yol açmıştır. Böylece haberci rolünü üstlenen bir birey paylaştığı içeriğin küresel çapta geniş kitlelere ulaşabilmesi için içeriği çeşitli sosyal medya platformlarından aynı anda paylaşma çabasındadır. Örneğin, kurum aidiyeti yüksek olan çalışanlar adeta birer haber ajansı görevi görerek kurumda gerçekleșen bir olayı, başarı hikayesini, iş paylaşımlarını kurumu etiketleyerek sosyal medya platformlarından yaymaktadır. Böylece sosyal medya ağlarının yeni nesil haberciliğin diğer bir ifade ile alternatif gazeteciliğin can damarı olduğu söylenebilir.

Diğer taraftan geleneksel gazeteciliğin yeni medya sayesinde katılımcı gazetecilik ile değiştiği üzerinde durulmaktadır (Lasica 2003; Singer ve diğ. 2011, s. 2). Burada katılımcı gazeteciliğin vatandaş gazeteciliğini içerdiği ve Twitter, tartışma forumları, blogların 
yorum bölümlerini de kapsayarak gerçekleștiği söylenebilir. 2018'de, özellikle sosyal medya sayesinde tüketicilerin artık pasif olmak yerine haberlerin içeriğini filtrelediği, tartıştığı ve oluşturulmasına yardımcı olduğu bir dönemin başladığı belirtilmektedir ve bugün haber medyasını anlamanın tek yolu bu dinamik, etkileşimli ortamı dikkate almaktır (Wilding ve diğ., 2018).

Diğer taraftan haber ajanslarının sosyal medya hesaplarından günlük haberleri paylaştıkları ve bağlantı (link) özelliği ile kurumsal web sitelerine yönlendirme yaparak kendi haber sitelerinin okuyucu sayısını arttırmaya çalıştığı görülmektedir. $\mathrm{Bu}$ bağlamda profesyonel destek alarak sosyal medya yönetimi yaptıkları ve takipçi sayılarını arttırmayı hedefledikleri söylenebilir. Önceleri Twitter haberciliği yapan haber ajanslarının şimdilerde Instagram'da hikâye paylaşarak kurumsal sitelerine yönlendirme yapmaları veya gönderi olarak haberleri görselleștirerek galerine de yerleștirerek akışta paylaşmaları, sosyal medya gazeteciliğine hikâye haberciliğinin eklenmesini sağlamıștır (Tutgun-Ünal, 2019b, 2020b).

Maares ve Hanusch (2018), yaptıkları bir araştırmada profesyonel Instagramcıların gazetecilik sınırlarının ve rol algılarının söylemsel yapılarını inceleyerek temel değerlerinin ve işlevsel yaklaşımlarının geleneksel gazetecilik meslek ideolojilerine benzediği öne sürerek Instagram gazeteciliğine dikkatleri çekmiştir. Böylece gazetecilik mesleğine bürünen vatandaşların olsun, profesyonel gazeteciler olsun sosyal medya gazeteciliği yaptıkları söylenebilir.

Böylece sosyal medya ortamında gerçekleşen ve tüm çevrimiçi kullanıcıları kapsamına alan "sosyal medya gazeteciliğinin" giderek geniş kitlelere hitap ettiği anlaşılmaktadır. Bu noktada geniş kitlelere haber sağlamayı görev bilen haber ajanslarının sosyal medya gazeteciliği açısından ne durumda olduklarının bilinmesi haber kontrolünün sosyal medya ağlarından yapıldığı günümüzde oldukça önemlidir. Aynı zamanda her bir sosyal medya uygulamasının kendi içindeki özellikler dikkate alındığında, gerçekleștirilen gazeteciliğin de kendine özgü doğası olacağı açıktır. Bu noktadan hareketle, bu araştırmada haber ajanslarının sosyal medya gazeteciliği açısından incelenmesi amaçlanmıştır. Bu amaç doğrultusunda aşağıdaki araştırma sorularına cevap aranmıştır:

1. Facebook gazeteciliği açısından karşılaştırıldığında hangi haber ajansının takipçi sayısı ve haftalık takipçi artış oranı en yüksektir?

2. Facebook gazeteciliği açısından karşılaştırıldığında haber ajanslarının haftalık ileti artışları ve ileti türleri nelerdir?

3. Twitter gazeteciliği açısından karşılaştırıldığında hangi haber ajansının takipçi sayısı ve haftalık takipçi artış oranı en yüksektir?

4. Twitter gazeteciliği açısından karşılaştırıldığında haber ajanslarının haftalık ileti artışları ve ileti türleri nelerdir?

5. Instagram gazeteciliği açısından karşılaştırıldığında hangi haber ajansının takipçi sayısı ve haftalık takipçi artış oranı en yüksektir?

6. YouTube yayıncılığı açısından karşılaştırıldığında hangi haber ajansının takipçi sayısı ve haftalık takipçi artış oranı en yüksektir?

\section{1. İnternet Gazeteciliğinden Sosyal Medya Gazeteciliğine Geçiş}

Önceleri geleneksel gazetecilik ile internet gazeteciliğinin fonksiyonelliği tartışılırken şimdilerde sosyal medya ortamlarında gerçekleştirilen gazetecilik ile tartışmalar 
bambaşka bir hal almıștır. Geleneksel gazetelerin kurumsal sitelerinden de haberleri paylaşmaları ve yenilerini gün içinde ekleyebilmeleri mümkünken sosyal medya ağlarında da hesap açarak habercilik yapmaları gazeteciliğin yönünün geniş bir yelpazeye kaymasına yol açmıştır.

İrvan (2014), internet gazeteciliğinin geleneksel medyada (gazete, radyo, televizyon) yapılan gazetecilikten farklı özelliklere ve avantajlara sahip olduğunu ve en önemli ayrım noktasının hipermetinler yani bağlantılar (link) olduğunu belirtmektedir. Bağlantılar özelliği sayesinde haberde geçen bir kavram, rapor, belge veya başka bir haber eğer internette farklı bir alanda yer alıyorsa oraya link verilebiliyor veya dosya olarak sayfaya yüklenebiliyor. Diğer avantaj ise, internet gazeteciliğinin dinamik olması olarak belirtilmektedir. Böylece, istenirse her yarım saatte bir farklı haberin manşete taşınarak okuyucu ile buluşması sağlanabilmektedir (İrvan, 2014).

Teknolojik gelişmeler ekonomik olarak daha ucuz iş yapma şekillerini ortaya çlkararak yeni meslek alanlarını da beraberinde getirirken, artık geleneksel bir gazetede olduğu gibi bir haberin baştan sona okunması yerini göz atma alışkanlığına bırakmıştır. Özellikle gençler ile yürütülen internet ve sosyal medya kullanım alışkanlıkları araștırmalarında Y ve Z kuşaklarının çabuk sıkıldığı ve içeriği kolayca tüketip yenisini talep ettiği, uzun süreler ayırıp bir sayfayı baştan aşağı okuma alışkanlıklarının olmadığı görülmektedir (Ekşili ve Antalyalı, 2017; Özdemir, 2017; Turgut, 2013; Tutgun-Ünal, 2013; Tutgun-Ünal ve Deniz, 2019).

Sosyal medyanın çoğunlukla gençler tarafından yoğun kullanıldığı araştırmalarda belirtilmektedir (Akyazı ve Tutgun-Ünal, 2013; Park ve diğ., 2018; Özdemir, 2017; TutgunÜnal ve Deniz, 2019). Şimdilerde yapılan güncel bir kuşak araştırmasında Tutgun-Ünal ve Deniz (2019) 1980-1999 yılları arasında doğan Y kuşağı ile 2000 ve sonrası doğan Z kuşağı gençlerinin birinci sırada Instagram uygulamasını kullandığını belirtmektedir. Baby Boomer, X, Y ve Z kuşaklarından oluşan 516 sosyal medya kullanıcısı ile yürütülen araştırmada $\mathrm{Y}$ ve $\mathrm{Z}$ gençlerinin daha çok görsel paylaşımlara dayanan Instagram ve YouTube uygulamalarını ilk iki sırada tercih ettiği ve en çok müzik ile video içeriklerini beğendikleri bulunmuştur. Bu durum daha çok genç kuşağa hitap etmek isteyen haber ajanslarının artık görsel haberciliğe diğer bir ifade ile Instagram ve YouTube haberciliğine yönelmesini ihtiyaç haline getirmiştir.

Görsel paylaşıma önem veren genç kuşaklara haber sunulurken fotoğraf/video, kısa metinler ile bakıp geçebilecekleri biçimde haberin kurgulanması özelliklerine ve bakış açılarına uygunluğu da sağlandığında etkili olabilmektedir. Ayrıca, hikâye özelliğinin pek çok uygulamada aynı anda paylaşılabilecek şekilde entegrasyonunun da sağlandığı görülmekte olup belirli süre sınırlaması sayesinde hikâye uzun olsa bile kısa kısa parçalara bölünmesi gerekmekte olduğundan genç kuşağın içeriğe bakıp geçmesini olanaklı kılan özellikleri barındırmaktadır (Atalay, 2020; Tutgun-Ünal, 2019b, 2020b).

Sosyal medya gazetecilikte önemli bir rol oynamaktadır. Gazetecilik yapanların meslek alanlarında bağımsız olarak seslerini duyurmalarını, bilgiyi halka yaymalarını ve diğer profesyonel ilişkilerini devam ettirmelerini sağlamada sosyal medya uygulamaları önemli bir araç olarak görülmektedir. 2012-2017 yılları arasında belirli aralıklarla yürütülen Cision Global Sosyal Gazetecilik Çalışmasına göre, gazetecilerin günlük haber paylaşımı için sosyal medya kullanımı yüzde on iki artış göstermiş olduğu da bu durumu doğrulamaktadır. Öyle ki, gazetecilerin sosyal medya platformlarındaki günlük olarak artan miktardaki düzenli gönderileri sosyal medya fenomenlerininkine benzetilmekte 
olup hatta sosyal medya yönetimi yapan organizasyonlara profesyonel gazeteciler derneğinin de eklendiği belirtilmektedir (Medium, 2018).

Gelinen noktada, sosyal medyanın haber ajansı görevi gördüğü günümüzde pek çok örnekte olay yeri fotoğrafı ve videolar ile birinci kaynak olarak haber kuruluşlarına hizmet ettiği ve gazetecilerin neredeyse tamamına yakınının sosyal medya mecralarından yararlandığı görülmektedir. Bu noktada vatandaşların çektikleri fotoğraf ve videoları paylaşarak birinci ağıdan enformasyon yayması ile haberciliğe dahil olmaları giderek yaygınlaşan bir durumdur. Böylece sosyal medya platformları habercilik yapmak isteyen vatandaşların bağımsız olarak video kurgulama ve metin yazarlığı beceriyle kendilerini geliştirme ortamları olarak fonksiyonel olmaktadır.

Daha da ötesi sosyal medya ağlarında ücretsiz olarak işletme hesabı açabilen bir kullanıcı kendi haberlerini yaparak imkanları dahilinde reklam da vererek kolay şekilde kendi tanıtımını yapabilmekte, adeta bir gazeteci gibi haber kurgularını oluşturup yayınlayabilmektedir. Böylece sosyal medyada yoğun vakit geçiren kuşakların haber alma ve üretme ihtiyacını karşılamada internet gazeteciliğine karşın yeni bir gazetecilik anlayışı olarak "sosyal medya gazeteciliği” kavramının ortaya çıkması kaçınılmaz olmuştur.

\section{Sosyal Medya Gazeteciliği ve Özellikleri}

Gazetecilik yapan bir kişinin sosyal ağlarda paylaşım yaparken gerçekten sosyal medya üzerinden çevrimiçi dünyaya bir şey söylemeyi isteyip istemediği önemlidir. Hatta, paylaşım veya yorum yaparken bir adım geriye dönüp "Bunu çevrimiçi dünya ile paylaşmayı gerçekten istiyor muyum?", "Bu yorum acaba birine zarar verir mi?" gibi soruları sorgulaması gerekmektedir. Özellikle gazetecilik mesleğini profesyonel olarak yapan birinin yaptığı paylaşımların etkileme gücünün de mesleki kabul görmüşlüğünden dolayı fazla olacağından daha dikkatli ve profesyonel olunması gerekmektedir. Bu yüzden sosyal medyadaki yorum ve görüş dengesini tutturmak önemli görülmektedir.

Haber kuruluşlarında çalışanların yaptıkları gazeteciliğe ilave olarak vatandaşların da birer gazeteci gibi davranması araştırmacıların sosyal medya kullanım alışkanlıklarını sorgulamasına yol açmıştır. Çünkü gazeteciliği iş edinen bir kişi nasıl düzenli olarak haber yapımına katkıda bulunuyorsa, vatandaşlar da aynı şekilde düzenli içerik paylaşımında bulunmaya eğilim göstermektedir. Tutgun-Ünal'a göre (2020b), akademisyenler de işleri ile ilgili olarak sosyal medyada haber yapma eğilimindedir (Tutgun-Ünal, 2020b, s. 81). Araştırmacıların pek çok yaş grubundan kullanıcılarla yürüttüğü sosyal medya alışkanlıklarını ve tercihlerini belirlemeye yönelik araştırmalar ne tür içeriklerin beğenildiği, hangi sosyal medya uygulamalarının daha çok tercih edildiği, günün hangi vakti sosyal medyanın kullanıldığı gibi durumların ortaya çıkmasını sağlamaktadırlar (Tutgun-Ünal, 2015, 2019, 2020a; Tutgun-Ünal ve Deniz, 2019, 2020).

Diğer yandan haber kuruluşlarının veya vatandaşların yaptığı habercilik konusunda sosyal medyanın rolünün incelendiği pek çok araştırmaya rastlanmaktadır (İrvan, 2014; Kıyan ve Törenli, 2018; Tutgun-Ünal ve Katmer-Bayraklı, 2014; Vis, 2013). Kıyan ve Törenli (2018), haber kuruluşlarında yönetici pozisyonunda çalışan kişilerin de sosyal medyayı haber kaynağı olarak ve haber verme kanalı olarak kullandıklarını belirtmektedir. Özellikle Twitter üzerinde yapılan araștırmalarda bu alanın haber amaçlı kullanıldığı ve atılan tweetlerin büyük çoğunluğunun haber içerikli olduğu sonucuna varılmış olup Twitter'ın bir "sosyal ağ platformu" olmaktan çok, "haber medyası platformu" olarak tanımlanabileceği belirtilmektedir (Kıyan ve Törenli, 2018; Kwak ve diğerleri, 2010; Lasorsa ve diğ., 2012). 
Diğer taraftan sosyal medya platformları aynı zamanda spekülasyonlara açık alanlar olduğundan haberin alınması sürecinde doğruluğunun da araştırılması gerekmektedir. Günlük bireysel kullanımda olsun kurumsal haber ajansları kapsamında olsun paylaşılan haberlerin doğruluğu o konuda paylaşılan diğer gönderilerle birlikte karşılaştırılarak da denetlenebilmektedir. Böylece sosyal medya gazeteciliğine özgü olarak denetim metodu da sosyal medya ağlarının kendi içinde gerçekleşebilmektedir.

Bu bağlamda, hashtag (\#) mekanizması kullanılarak yayılan enformasyonların bir araya getirilerek varsa farklı görüşlerinde görüntülenmesine olanak sağlanmaktadır. Sosyal medyanın kendi iç denetim mekanizmasında denetçiler bir nevi çevrimiçi kullanıcılar olup görüş paylaşımında, beğeni alışverişinde veya tekrar paylaşımda (retweet, repost, repin vb.) bulunabilmektedir. Böylece haberin farklı açılardan yorumlanması ile etkileşim ve devamlılık sağlanmaktadır. Böylece çevrimiçi ağlarda genişleyerek yayılım gösteren yeni bir gazetecilik anlayıșı ortaya çıkmaktadır.

Diğer yandan, internet medyasıyla son elli yılda gazeteciliğe ve haber medyasına duyulan güvenin sarsıldığını belirten bir raporda, gazeteciliğin teorik değeri geniş çapta kabul görmeye devam etse de uygulamasının giderek zor hale geldiği belirtilmektedir (Wilding ve diğ., 2018). Böylece dijital platformların ortaya çıkışıyla (1998'de Google, 2004'te Facebook, 2006'da Twitter vb.) haberin değiștirilip değiştirilmediğinin de araștırılması gerekliliği de ortaya çıkmıştır.

Diğer bir önemli nokta olarak haberin tüketimi, dağıtımı ve üretiminin temelde değişikliğe uğraması olduğu belirtilmektedir. Bir zamanlar haber üreticileri aynı zamanda distribütörleri (dağıtımcıları) olma eğilimindeyken şimdilerde tüketicilerin dijital platformlarda distribütör rolünü de üstlendiği vurgulanmaktadır (Wilding ve diğ., 2018). Sosyal medya gazeteciliğinde haberin üreticileri, tüketicileri ve dağıtımcıları da çevrimiçi kullanıcılar olup yatay iletişim modelinde olduğu gibi eşitlenmiş seviyededir. Haber ajansları açısından bakıldığında, haberin dağıtımında önemli role sahip oldukları bildirilmekte olup haber kuruluşlarından ve özellikle sosyal medya gibi dijital platformlardan kontrol edilmektedir.

Haber tüketimine yönelik yapılan bir araştırmada Avustralyalıların mobil telefonlarından erişim sağlayarak her geçen gün daha çok çevrimiçi haber tükettiği, 2016 yılından 2018 yılına kadar iki sene içinde yüzde on beş artış gösterdiği bulunmuştur. Araştırmaya göre, Avustralyalıların yüzde sekseninden fazlası günde en az bir kere çevrimiçi olarak haberlere erişmekte, yüzde elli altısı ise günde birden fazla erişmektedir (Park ve diğ., 2018, s.8). Diğer yandan sosyal medya kuşaklarına yönelik yapılan bir araştırmada haber içeriklerinin beğeni oranı Baby Boomer ve X Kuşaklarında yüksek bulunması günümüzde haber tüketiminde sosyal medya ağlarının popülerlik kazandığını göstermektedir (Tutgun-Ünal ve Deniz, 2020).

Sosyal medyanın ortaya çıkışıyla haber anlayıșı ve tanımlamaların da değişikliğe uğradığı görülmektedir. Böylece yorum ve haber ayrımının giderek bulanıklaştığı birbiri içinde zaman zaman geçişkenlik gösterdiği ve haber tanımlamalarının daha geniş ele alındığ belirtilmektedir (Lamble, 2011; Marwick 2018, p. 504; Wilding ve diğ., 2018). Böylece sosyal medya gazeteciliği ile haber tanımlarının yenilendiği söylenebilir.

Wilding ve diğerleri (2018) gazeteciliği, enformasyon toplayarak ve hikâye anlatımı tekniklerini kullanarak haber üretme pratiği olarak tanımlamaktadır. Yeni medya ile özellikle gazetecilerin değil gazetecilik içeriğinin kabul gördügünün vurgulanması sosyal 
medyada üretilen haber maksatlı içeriklerin sosyal medya gazeteciliğine hizmet ettiğini ortaya koymaktadır.

Böylece, sosyal medya gazeteciliği kendine özgü özellikleri ile ön plana çıkmaktadır. (CIJP, 2017):

1. Vatandaşlara dünyada olup bitenler hakkında güncel bilgi sağlamak.

2. Seçimler, ekonomi ve sosyal yaşama dair güvenilir içerikler sağlamak.

3. Fikir alışverişi için forum görevini sağlamak.

4. İktidar hakkında bilgi sahibi olmak.

5. Toplumların kendilerini anlamalarına yardımcı olmak.

6. Toplumun üyelerinin ortak bir sohbete dayanabileceği materyali sağlamak.

Sosyal medya platformlarının küresel iletişimin sağlanmasına aracılık etmesi, istenilen enformasyonun metin, fotoğraf, video gibi pek çok türden içerikle sosyal medyada kolayca oluşturulabilmesi, gönderilerin paylaşılabilmesi, tartışılabilmesi ve hashtag (\#), Mention (@) gibi özellikler ile küçük veya büyük çapta konuya özel topluluklar oluşturulabilmesine olanak tanıması, politikacıların hesaplarını takip ederek karşılıklı konuşma veya paylaşımlar sayesinde görüşlerini anlamada aracılık etmesi, çevrimiçi tüm kullanıcıların gönderileri ile pek çok kişiyi ve yaşam tarzlarını anlamaya imkan sağlaması, trend topic olarak gündeme hangi konunun düştügünün takip edilmesi, takipçi ve beğeni sayıları gibi özellikler ile topluma öncü olma potansiyeli sağlaması, ağdaki arkadaşlar ve onların arkadaşlarına kadar paylașılan içerikler (metin, fotoğraf, video vs.) sayesinde konuşulacak konuların yaratılmasına imkan sağlaması sosyal medya gazeteciliğinin toplumsal etki sağlamaya hazır olduğunu ortaya koymaktadır. Küresel olarak paylaşılan enformasyonun çevrimiçi sosyal ağlardaki yayılım gücü göz önüne alındığında büyük bir etki yaratacak gazetecilik anlayışı ortaya çıkmaktadır.

Diğer taraftan McNair (2005, s.28) yeni medyanın üç temel fonksiyonu olduğunu açıklamaktadır: (1) Bireylerin ve grupların sosyal çevrelerini izlemeleri için gerekli bilgileri sağlayıcı gözetim aracı, (2) Özellikle liberal-demokratik toplumlarda, sosyolog Jurgen Habermas'ın (1989) kamusal alan olarak adlandırdığı şeyin söylemsel temeli için, kamusal hayata ve siyasi tartışmalara destek ve sıklıkla katılım kaynağı, (3) Eğitim, bilgilenme ve eğlence aracı. Söz konusu fonksiyonların şimdilerde yeni medya ile ortaya çıkan sosyal medya ağlarında sağlanmasıyla tüm alanlardaki çalışmaların yönü sosyal medya ağlarına kaymıștır. Sosyal Medya Gazeteciliği de bu alanlardan biri olarak oldukça dinamik ve güçlü görülmektedir.

Sosyal medyanın kendi doğasında gerçekleşen haber üretim, tüketim, dağıtım işlevlerinde kullanıcı modeli ile tüm işlevlerin tek birimde toplanması gazetecilikte dönüşüm yaratmıştır. Sosyal medya uygulamalarının her birinde özellikle görsel özelliklerin ön planda olması görsel bir gazetecilik anlayıșını gündeme getirmektedir. McQuail'e göre (2000, s. 340) her bir uygulamaya kullanıcılar farklı tatmin ihtiyacını sağlamak için katılım sağlamaktadır. Böylece pek çok sosyal medya uygulamasına farklı özelliklerdeki kullanıcılar talep göstermektedir.

\section{Sosyal Medya Gazeteciliği Uygulamaları}

Sosyal medya gazeteciliği çeşitli sosyal medya uygulamaları ile sağlanabilmektedir. Yapılan araştırmalarda sosyal medyanın haber alma amacıyla kullanımının sorgulandığı ve hangi uygulamaların bu amaca yönelik popülerlik sağladığının tespit edildiği görülmektedir (Akyazı ve Tutgun-Ünal, 2013; Park ve diğ., 2018; Tutgun-Ünal ve Deniz, 
2019, 2020; Wilding ve diğ., 2018). Buna göre, Pew Araştırma Merkezinin bir çalışması, Amerikalı yetişkinlerinin üçte ikisinin (yüzde altmış sekiz) sosyal medyadan haber aldığını ve daha çok Facebook'un haber almak için tercih edildiğini (yüzde kırk üç) göstermiş olup ikinci sırada YouTube (yüzde yirmi bir), üçüncü sırada Twitter (yüzde on iki) gelmiștir. Avustralya'da da ilk sırada Facebook haber almada ön plana çıkmaktadır (Park ve diğ., 2018).

Araştırmalar zaman geçtikçe farklı uygulamaların popüler olduğunu göstermiştir. Tutgun-Ünal ve Deniz'e (2020) göre orta yaş ve üzeri (1980'den önce doğanlar) Facebook kullanırken genç kuşaklar (1980 ve sonrası doğanlar) birinci sırada Instagram'ı kullanmaktadır. Özellikle 2000 yılı ve sonrası doğanların Instagram ve YouTube kullanım oranları birbirine yakın bulunmuştur. Ayrıca, haber alma amaçlı sosyal medya kullanımının en çok yetişkinlerde görüldüğünü belirten araştırmada gençlerin ise daha çok görsel içerikleri beğendiği ortaya çıkmıştır.

Sosyal medya uygulamalarının her geçen gün görsel özellikleri bünyesine katarak birbirine benzerlik gösterdiği görülmektedir. Örneğin Twitter'da gönderiler metin, fotoğraf, video gibi pek çok öğe ile oluşturulurken konum, mention, hashtag, bağlantı (link) verme özellikleri eklenebilmektedir. Böylece Twitter habercilikte oldukça yaygın kullanılmaktadır. Vatandaşların, politikacıların, popüler kişilerin ve haber ajanslarının attığı sayısız tweetler çevrimiçi ağlarda dolaşmakta ve etkileşim almaktadır.

Diğer taraftan Instagram uygulamasının pek çok araştırmada belirtildiği gibi özellikle gençler tarafından yoğun kullanılması görsel paylaşımları ön planda tutan uygulama üzerinden habercilik yapılmasını gündeme getirmiştir (Tutgun-Ünal, 2020a; Larsson, 2017). Böylece haber kaynağı veya hikâye bölümü ile genç kullanıcıların ilgisini çekecek pek çok özellik kullanılarak Instagram üzerinden habercilik yapılabilmektedir.

Instagram fotoğraf paylaşımına yönelik özellikleri ile ön planda olduğundan fotoğraf gazeteciliğine de hitap etmektedir. Bir araștırmada Instagram kullanıcılarının paylaşımlarındaki söylemler yapısal olarak incelenmiş olup gazetecilik meslek ideolojileriyle benzerlikler bulunmuştur (Maares ve Hanusch, 2018). Başka bir araştırmada altısı amatör altısı profesyonel olan12 foto muhabirinin Instagram fotoğraf galerileri incelenmiş, kullandıkları görseller ile kullanılan simülasyonlar ile söylemler analiz edilerek farklılıklar bulunmuştur. Paylaşılan fotoğraflarda düzenlemeler/filtreler yapıldığında dünyanın aşırı tasvirinin yaratıldığı ve foto muhabirliğinin gerçekliği vurgulayan doğasına ters düşüldüğü belirtilmiştir (Borges-Rey, 2015).

Ayrıca Y kuşağı olarak bilinen 1980-1999 tarihleri arasında doğanların Instagram kullanımında birinci sırada oldukları ve yüksek oranda $(\% 72,7)$ fotoğraf, video içeriklerini beğenmelerinin yanında güncel haber takibi yaptıklarının bulunması $(\% 64,5)$ Instagram Gazeteciliğinin Y Kuşağı gençliğine de yüksek oranda hitap edeceğini göstermektedir. Özellikle 2000 yılı ve sonrası doğanların diğer bir ifade ile teknolojiyle doğmuş olan Z kuşağının YouTube kullanım oranlarının Instagram kullanım oranlarına yaklaştığı belirtilen bir araştırmada \%84,4'ünün video içeriklerini beğendikleri belirtilmektedir (Tutgun-Ünal ve Deniz, 2020).

Böylece haber ajanslarının farklı sosyal medya uygulamalarındaki hesaplarından paylaştıkları iletiler hangi kullanıcı grubuna hitap etmek istedikleri hakkında fikir verebileceği gibi görsel paylașımların ön planda olduğu bir habercilik anlayıșını da sosyal medya ortamlarında ne şekilde yansıttıklarını ortaya koyacaktır. 


\section{Yöntem}

Araştırmada haber ajanslarının sosyal medya hesaplarının takipçi sayısı, takipçi artış oranı, paylaşılan içerik sayısı gibi değişkenler açısından incelenmesi amaçlandığından niceliksel betimleme yöntemi kullanılmıştır. Çalışma var olan durumun ortaya koyulmasına yönelik olduğundan genel tarama modeline göre yürütülmüştür. Genel tarama modelleri var olan durumun ortaya konulması amacıyla çok sayıdaki elemanı içeren bir evrende kullanılmaktadır (Karasar, 2018).

Araştırma örneklemini Türkiye'de takipçi sayısı açısından ilk üç sırada yer alan haber ajansları oluşturmaktadır. Haber ajanslarının Facebook, Twitter, Instagram ve YouTube sosyal medya hesapları Boomsocial sistemi kullanılarak incelenmiștir.

Boomsocial sisteminde yer haber ajanslarının Facebook, Twitter, Instagram ve Youtube hesapları sorgulanarak 2020 yılı Mart ayına ait bir haftalık zaman dilimindeki verileri araștırmaya alınmıștır. Elde edilen analizler sonucunda haber ajanslarının sosyal medya hesaplarındaki takipçi sayıları, haftalık takipçi artış oranları, bir haftada en fazla kaç tane ileti gönderdiği, gönderdiği ileti türlerinin ne olduğu ve hangi oranda hangi içerik türlerinden yararlandıkları verilerine ulaşılmıştır.

Her bir sosyal medya uygulamasında bahsi geçen veriler sorgulanarak haber ajanslarının sosyal medya hareketliliği tespit edilmeye çalışılmıştır. Sosyal medya gazeteciliği açısından elde edilen veriler yorumlanmıştır.

\section{Bulgular}

Araştırmada haber ajanslarının Boomsocial sistemi kullanılarak sosyal medya hesaplarının incelenmesiyle 2020 yılı Mart ayı içindeki bir haftanın takipçi sayıları, takipçi artış oranları, ileti sayıları ve ileti türleri tespit edilmeye çalıșılmıştır.

Bu bölümde araştırma soruları eşliğinde yapılan incelemelere yer verilmiştir.

Facebook gazeteciliği açısından haber ajanslarının takipçi sayıları ve haftalık artış oranlarının karşılaştırılmasına yönelik bulgular. Boomsocial sisteminde Mart 2020'ye ait haber ajansları Facebook hesapları incelenerek elde edilen veriler Tablo 1'de yer almaktadır.

Tablo 1: Haber Ajanslarının Facebook Hesapları-Mart 2020 (Boomsocial,2020)

\begin{tabular}{|l|c|c|c|c|c|}
\hline Facebook Hayran Sayfası & Hayran & HK & HA & HA (\%) & EO (\%) \\
\hline Anadolu Ajansı & 5.553 .274 & 98.764 & -606 & $\%-0,01$ & $\% 0,01$ \\
\hline ìhlas Haber Ajansı & 1.052 .600 & 11.161 & -400 & $\%-0,04$ & $\% 0,00$ \\
\hline Demirören Haber Ajansı & 137.467 & 64.176 & 1.506 & $\% 1,11$ & $\% 0,15$ \\
\hline
\end{tabular}

HK: Hakkında Konuşulanlar; HA: Hayran Artışı; EO: Etkileşim Oranı

Tablo 1 incelendiğinde, Anadolu Ajansının takipçi sayısının en yüksek olduğu görülmektedir. Haftalık artış oranları incelendiğinde takipçi sayıları açısından ilk iki sırada yer alan haber ajanslarının negatif yönde olduğu ortaya çıkmış, Demirören Haber ajansının ise pozitif yönde artışta olduğu görülmüştür.

Facebook gazeteciliği açısından haber ajanslarının haftalık ileti artışları ve türlerine yönelik bulgular. Bu bölümde araştırma kapsamına alınan ilk üç sıradaki haber ajansının haftalık ileti sayıları ve ne tür içerikler paylaștığı incelenmiş olup ilk olarak Anadolu Ajansının Mart ayına ait haftalık ileti artış grafiği ile ileti türleri grafiği verilmiştir. 


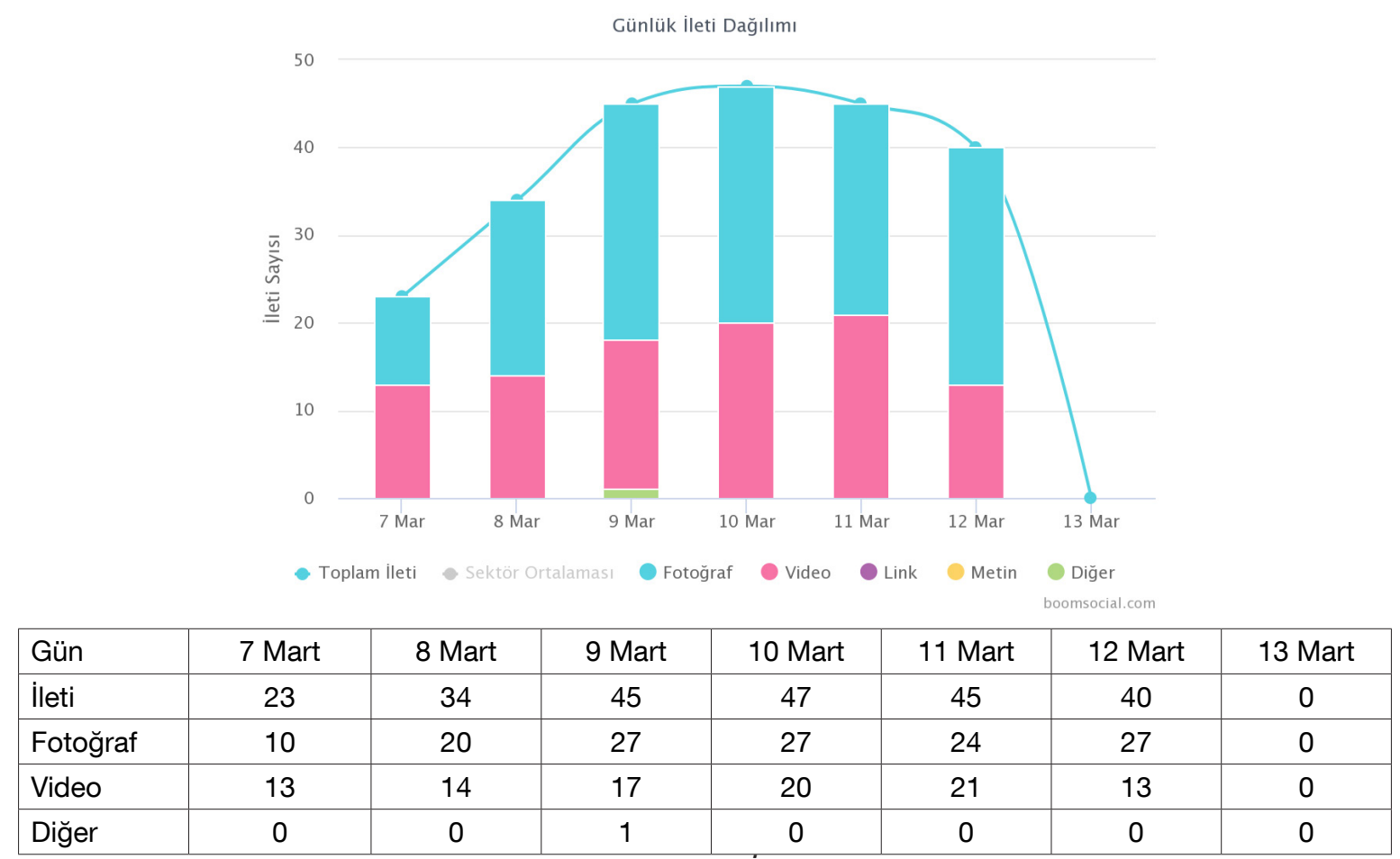

Grafik 1: Anadolu Ajansı Haftalık Facebook Illetileri, Mart 2020 (Boomsocial,2020)

Grafik 1'e göre Anadolu Ajansının haftalık ileti sayısının en yüksek olduğu gün 47 gönderi paylaştığı, günlere göre değişkenlik gösterdiği görülmektedir. İleti türlerine yönelik analizler incelendiğinde, \%41,9'unun video, \%57,7'sinin fotoğraf, \%0,4'ünün ise diğer türde içerikler olduğu görülmüştür.

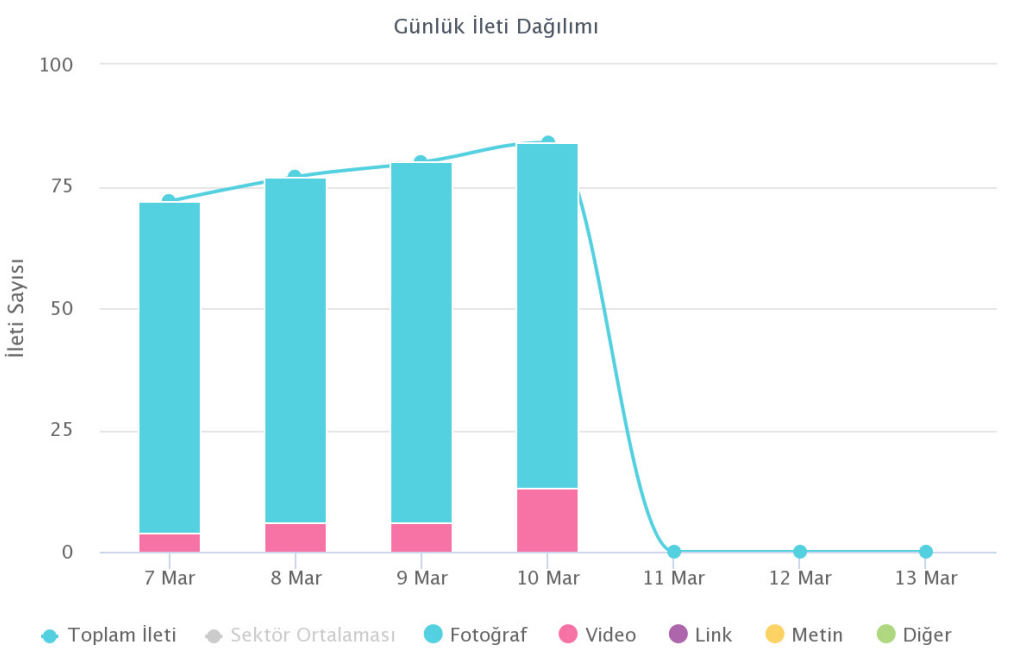

\begin{tabular}{|l|c|c|c|c|c|c|c|}
\hline Gün & 7 Mart & 8 Mart & 9 Mart & 10 Mart & 11 Mart & 12 Mart & 13 Mart \\
\hline İleti & 72 & 77 & 80 & 84 & 0 & 0 & 0 \\
\hline Fotoğraf & 68 & 71 & 74 & 71 & 0 & 0 & 0 \\
\hline Video & 4 & 6 & 6 & 13 & 0 & 0 & 0 \\
\hline Diğer & 0 & 0 & 0 & 0 & 0 & 0 & 0 \\
\hline
\end{tabular}

Grafik 2: İhlas Haber Ajansı Haftalık Facebook IIletileri, Mart 2020 (Boomsocial,2020)

Grafik 2 incelendiğinde, İhlas Haber Ajansının haftalık ileti sayısının en yüksek olduğu gün 84 ileti paylaştığı, bazı günlerde ise hiç paylaşım yapmadığı görülmektedir. \%90,7 oranında fotoğraf, $\% 9,3$ oranında ise video paylaşıldığı belirlenmiştir. 


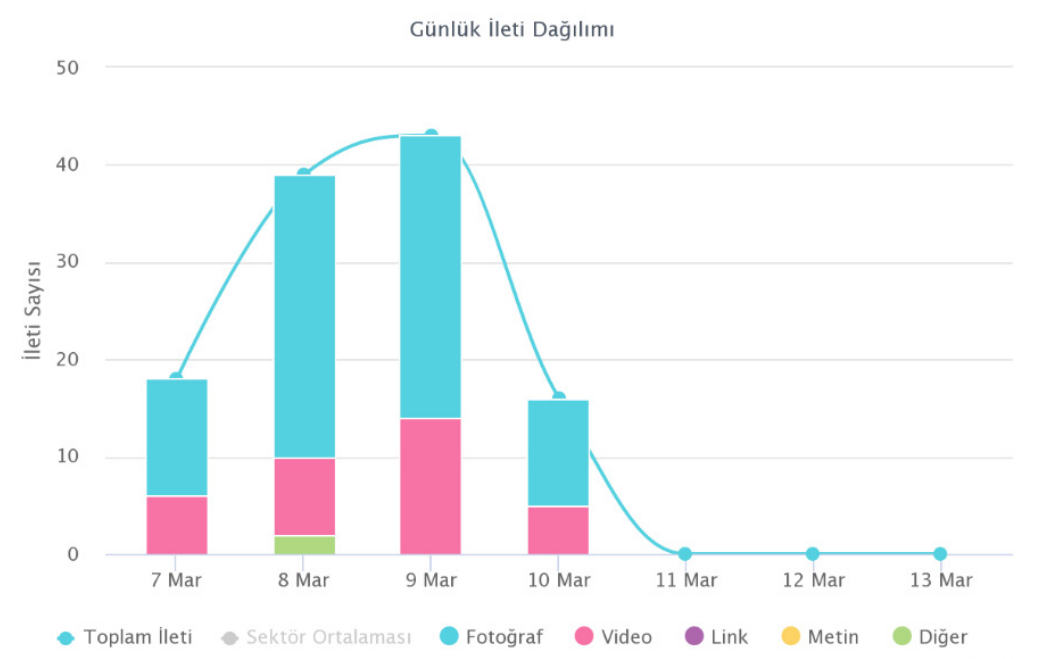

\begin{tabular}{|l|c|c|c|c|c|c|c|}
\hline Gün & 7 Mart & 8 Mart & 9 Mart & 10 Mart & 11 Mart & 12 Mart & 13 Mart \\
\hline İleti & 18 & 39 & 43 & 16 & 0 & 0 & 0 \\
\hline Fotoğraf & 12 & 29 & 29 & 11 & 0 & 0 & 0 \\
\hline Video & 6 & 8 & 14 & 5 & 0 & 0 & 0 \\
\hline Diğer & 0 & 2 & 0 & 0 & 0 & 0 & 0 \\
\hline
\end{tabular}

Grafik 3: Demirören Haber Ajansı Haftalık Facebook Iletileri, Mart 2020 (Boomsocial,2020)

Grafik 3 incelendiğinde, Demirören Haber Ajansının haftalık ileti sayısının en yüksek olduğu gün 43 ileti paylaştığı, bazı günlerde ise hiç ileti paylaşmadığı görülmektedir. Paylașılan ileti türleri incelendiğinde, $\% 69,8$ oranında fotoğraf, $\% 28,4$ oranında video türünde içerik paylaştığı, \%1,7 oranında ise diğer türlerde paylaşım yaptığı belirlenmiştir.

Twitter gazeteciliği açısından haber ajanslarının takipçi sayıları ve haftalık artış oranlarının karşılaştırılmasına yönelik bulgular. Boomsocial sisteminde Mart 2020'ye ait haber ajansları Twitter hesapları incelenerek elde edilen veriler Tablo 2'de yer almaktadır.

Tablo 2: Haber Ajanslarının Twitter Hesapları-Mart 2020 (Boomsocial,2020)

\begin{tabular}{|l|c|c|c|c|c|}
\hline Twitter Hesabı & Takipçi & T. Ettiği & HA & HA (\%) & E0 (\%) \\
\hline Anadolu Ajansı & 2.500 .996 & 27 & 26.806 & $\% 1,08$ & $\% 0,01$ \\
\hline Demirören Haber Ajansı & 1.131 .910 & 7 & 2.476 & $\% 0,22$ & $\% 0,00$ \\
\hline İhlas Haber Ajansı & 743.857 & 25 & 3.313 & $\% 0,45$ & $\% 0,00$ \\
\hline
\end{tabular}

HA: Hayran Artışı; EO: Etkileşim Oranı

Tablo 2 incelendiğinde, Anadolu ajansının takipçi sayısı ile ilk sırada yer aldığı, ikinci sırada Demirören Haber Ajansının, üçüncü sırada ise İhlas Haber Ajansının yer aldığı görülmektedir. Haftalık takipçi artış oranlarına bakıldığında, pozitif yönde artış oranlarına sahip oldukları gözlenmektedir.

Twitter gazeteciliği açısından haber ajanslarının haftalık ileti artışları ve türlerine yönelik bulgular. Bu bölümde araştırma kapsamına alınan ilk üç sıradaki haber ajansının haftalık ileti sayıları ve ne tür içerikler paylaştığı incelenmiştir. 


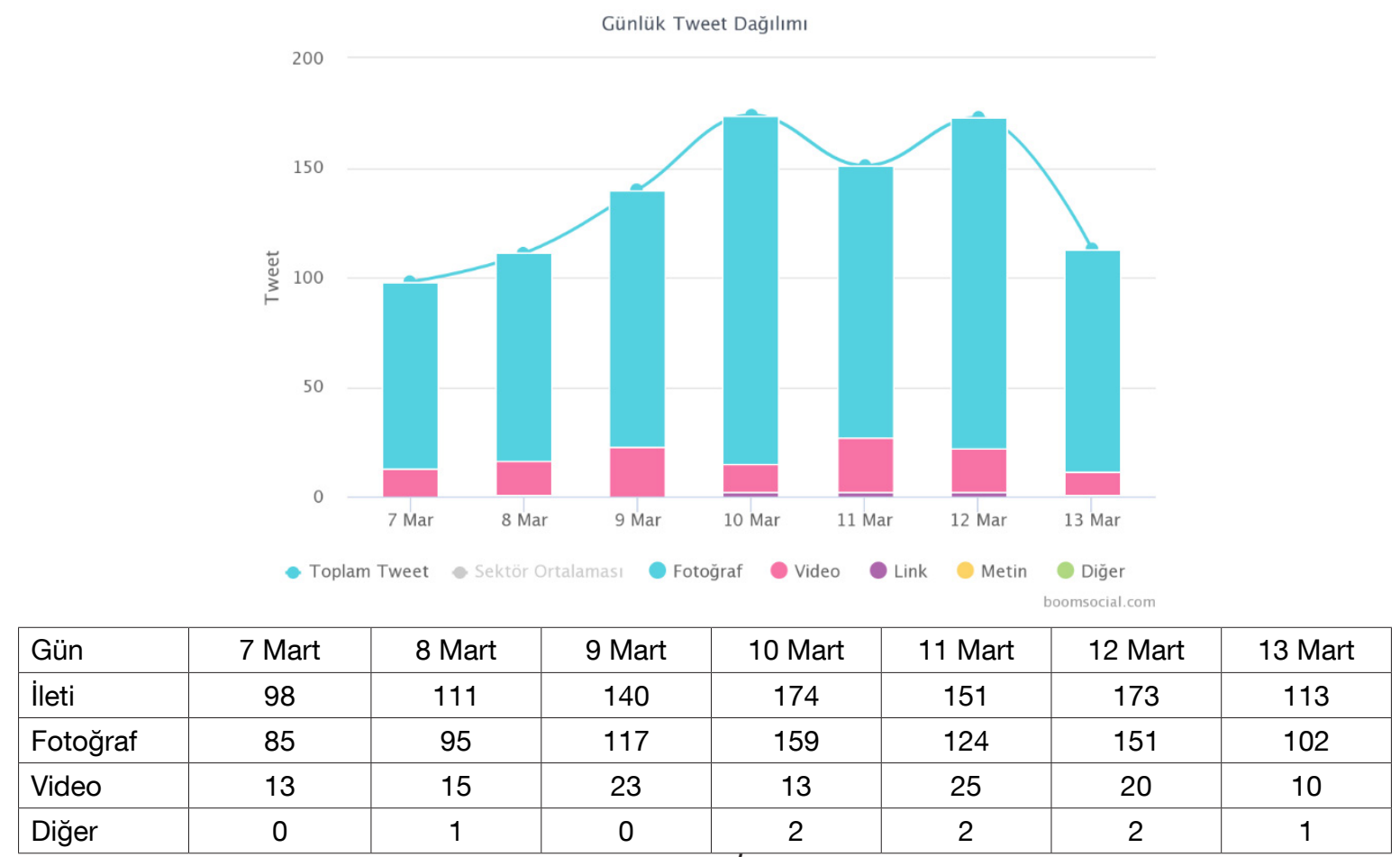

Grafik 4: Anadolu Ajansı Haftalık Twitter Illetileri, Mart 2020 (Boomsocial,2020)

Grafik 4 incelendiğinde, Anadolu Ajansının haftalık attığı tweetlerin en yüksek olduğu gün 174 tweet attığı görülmektedir. Atılan tweetlerin \%86,8'inin fotoğraf, \%12,4'ünün video, \%0,8'inin diğer türden içerik olduğu belirlenmiştir.

Günlük Tweet Dağılımı

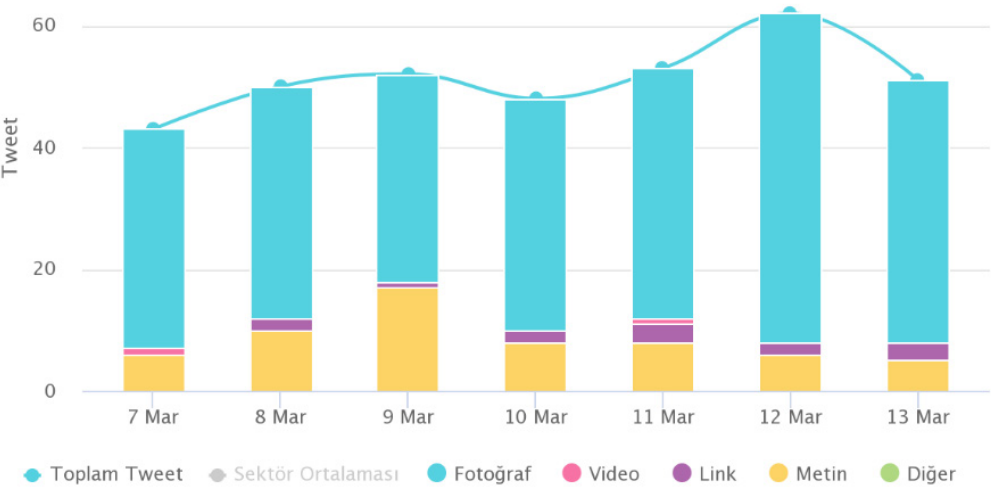

\begin{tabular}{|l|c|c|c|c|c|c|c|}
\hline Gün & 7 Mart & 8 Mart & 9 Mart & 10 Mart & 11 Mart & 12 Mart & 13 Mart \\
\hline İleti & 43 & 50 & 52 & 48 & 53 & 62 & 51 \\
\hline Fotoğraf & 36 & 38 & 34 & 38 & 41 & 54 & 43 \\
\hline Video & 1 & 0 & 0 & 0 & 1 & 0 & 0 \\
\hline Metin & 6 & 2 & 17 & 8 & 8 & 6 & 5 \\
\hline Link & 0 & 0 & 0 & 0 & 3 & 2 & 3 \\
\hline
\end{tabular}

Grafik 5: Demirören Haber Ajansı Haftalık Twitter Illetileri, Mart 2020 (Boomsocial,2020)

Grafik 5’e göre, Demirören Haber Ajansının bir hafta boyunca attığı tweetlerin en yüksek olduğu gün 62 tweet attığı görülmektedir. Atılan tweetlerin \%79,1'inin fotoğraf, \%16,7’sinin metin, \% 0,6'sının video, \%3,6'sının link olduğu belirlenmiştir. 


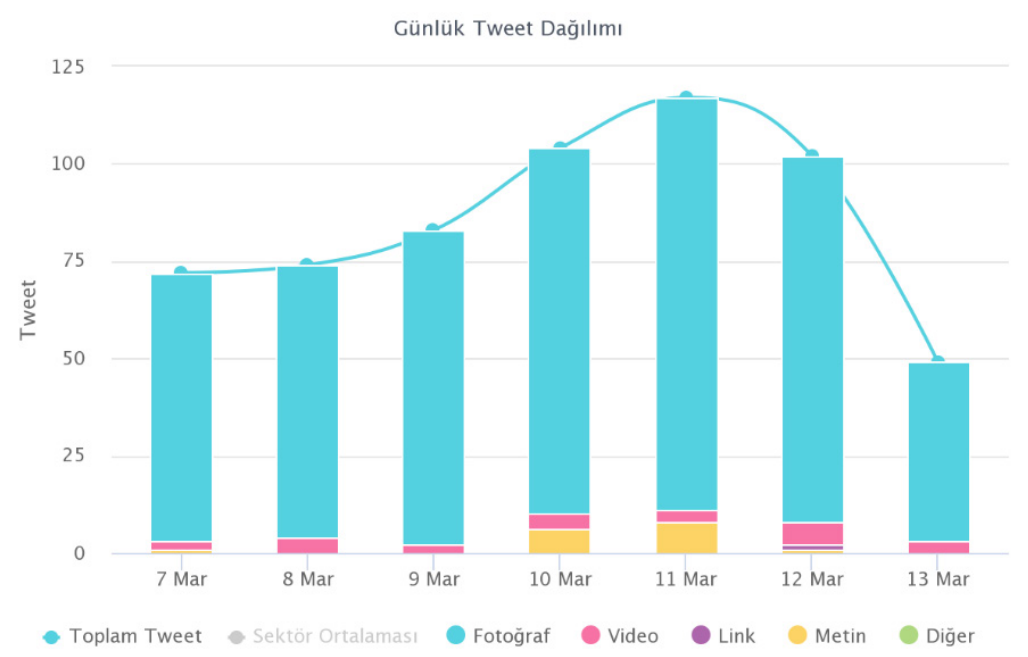

\begin{tabular}{|l|c|c|c|c|c|c|c|}
\hline Gün & 7 Mart & 8 Mart & 9 Mart & 10 Mart & 11 Mart & 12 Mart & 13 Mart \\
\hline İleti & 72 & 74 & 83 & 104 & 117 & 102 & 49 \\
\hline Fotoğraf & 69 & 70 & 81 & 94 & 106 & 94 & 46 \\
\hline Video & 2 & 4 & 2 & 6 & 3 & 6 & 3 \\
\hline Metin & 1 & 0 & 0 & 6 & 8 & 1 & 0 \\
\hline Link & 0 & 0 & 0 & 0 & 0 & 1 & 0 \\
\hline
\end{tabular}

Grafik 6: Ihlas Haber Ajansı Haftalık Twitter İletileri, Mart 2020 (Boomsocial,2020)

Grafik 6 incelendiğinde, İhlas Haber Ajansının bir hafta boyunca en fazla tweet attığı gün 117 tweet attığı görülmektedir. Atılan tweetlerin \%93,2'sinin fotoğraf, \%4'ünün video, $\% 2,7$ 'sinin metin, \%0,2'sinin link türünde olduğu belirlenmiștir.

Instagram gazeteciliği açısından haber ajanslarının takipçi sayıları ve haftalık artış oranlarının karşılaştırılmasına yönelik bulgular. Boomsocial sisteminde Mart 2020'ye ait haber ajansları Instagram hesapları incelenerek elde edilen veriler Tablo 3'te yer almaktadır.

Tablo 3: Haber Ajanslarınin Instagram Hesapları-Mart 2020 (Boomsocial,2020)

\begin{tabular}{|l|c|c|c|c|c|}
\hline Instagram Hesabı & Takipçi & Medya & HA & HA (\%) & EO (\%) \\
\hline Anadolu Ajansı & 982.208 & 6.126 & 7.533 & $\% 0,77$ & $\% 0,46$ \\
\hline İhlas Haber Ajansı & 204.290 & 3.318 & 2.215 & $\% 1,10$ & $\% 0,50$ \\
\hline Demirören Haber Ajansı & 36.878 & 1.747 & 1.747 & $\% 4,30$ & $\% 0,55$ \\
\hline
\end{tabular}

HA: Hayran Artışl; EO: Etkileşim Oranı

Tablo 3 incelendiğinde, Instagram takipçi sayısı en yüksek haber ajansının Anadolu ajansı olduğu görülmektedir. İkinci sırada İhlas Haber Ajansı, Üçüncü sırada ise Demirören Haber Ajansı gelmektedir. Fakat haftalık takipçi artış oranı en yüksek olan ajansın Demirören Haber Ajansı olduğu görülmektedir.

YouTube yayıncılığı açısından haber ajanslarının takipçi sayıları ve haftalık artış oranlarının karşılaştırılmasına yönelik bulgular. Boomsocial sisteminde Mart 2020'ye ait haber ajansları YouTube hesapları incelenerek elde edilen veriler Tablo 3'te yer almaktadır. 
Tablo 4: Haber Ajanslarının YouTube Hesapları-Mart 2020 (Boomsocial,2020)

\begin{tabular}{|l|c|c|c|c|c|}
\hline Youtube Video Kanalı & Abone & İzlenme & HA & HA (\%) & EO (\%) \\
\hline İhlas Haber Ajansı & 641.000 & 555.724 .989 & 3.000 & $\% 0,47$ & $\% 0,01$ \\
\hline Anadolu Ajansı & 335.000 & 215.580 .507 & 3.000 & $\% 0,90$ & $\% 0,17$ \\
\hline Demirören Haber Ajansı & 291.000 & 230.574 .115 & 5.000 & $\% 1,75$ & $\% 0,03$ \\
\hline
\end{tabular}

HA: Hayran Artışı; EO: Etkileşim Oranı

Tablo 4 incelendiğinde, abone sayısıyla İhlas Haber Ajansı kanalının birinci sırada geldiği görülmektedir. İkinci sırada Anadolu Ajansı, üçüncü sırada Demirören Haber Ajansı gelmektedir. Haftalık abone artışlarının genel olarak pozitif yönde olduğu görülmekte olup en yüksek artıș oranı Demirören Haber ajansına aittir.

\section{Sonuç}

Araştırmada sosyal medya platformlarında yer alan haber ajanslarının hareketliliği araştırma soruları eşliğinde tespit edilmeye çalışılmıştır. 2020 yılı Mart ayı hareketliliklerinin incelenebilmesi için Boomsocial verilerinden yararlanılmıştır. Böylece haber ajanslarının takipçi artışı, ileti sayıları ve ileti türleri yönündeki yaptıkları çalışmalar sosyal medya gazeteciliği açısından karşılaştırılmıştır.

Buna göre, haber ajanslarının Facebook, Twitter ve Instagram hesapları incelendiğinde takipçi sayısı açısından Anadolu Ajansının ilk sırada olduğu görülmektedir. Fakat haftalık takipçi artış oranlarına bakıldığında Facebook'ta takipçi sayısı açısından üçüncü sırada olan Demirören Haber Ajansının pozitif yönde takipçi artışına sahip olduğu, ilk iki sıradaki haber ajanslarının negatif yönde olduğu görülmüştür.

Diğer yandan haftalık ileti paylaşımlarına bakıldığında Anadolu Ajansının düzenli olarak içerik paylaşımında bulunduğu, Demirören ve İhlas haber ajansının hiç ileti paylaşmadığı günler olduğu ortaya çıkmıştır.

Facebook'ta paylaşılan içerik türleri incelendiğinde Anadolu Haber Ajansının video ve fotoğraf türünde orantısal olarak dengeli paylaşımlarda bulunduğu görülmüştür. İhlas Haber Ajansı ise \%90 oranında fotoğraf paylaşımında bulunurken, \%10'un altında video paylaşımında bulunduğu ortaya çıkmıştır. Demirören Haber Ajansının ise \%70'e yakın yine fotoğraf paylaştığı video paylaşımının ise \%28 olduğu görülmüştür.

Araştırmalarda sosyal medya ağlarında çeşitli türden içerikleri talep eden pek çok yaş grubundan kullanıcının olduğu belirtilmektedir (Larsson, 2017; Tutgun-Ünal, 2020a; Tutgun-Ünal ve Deniz, 2019, 2020). Bu bağlamda içerik çeşitliliğinin sağlanması daha geniş çapta kitlelere hitap etmede fonksiyonel olabilmektedir.

Twitter hesapları incelendiğinde, takipçi sayısı ve haftalık takipçi oranı açısından birinci sırada Anadolu Ajansının geldiği, ikinci sırada Demirören Haber Ajansının olduğu görülmüştür. İhlas Haber Ajansı ile Anadolu Ajansının haftalık olarak izlendiğinde en çok tweet attığı ve atılan tweetlerin ortalama $\% 90$ fotoğraf türünde olduğu belirlenmiștir. Burada Demirören Haber Ajansının attığı tweetler'de metin kullanımının da dengeli olarak günlere yayılması dikkat çekmektedir. Diğer ajanslara oranla metin kullanımının neredeyse \%20'ye yakın bulunması haber paylaşımlarının twitter'da metin okumaya alışkın olan kesime de hitap ettiğini göstermektedir. Buna karşın birinci sırada olduğu görülen Anadolu Ajansının Twitter paylaşımlarında metin kullanmadığı, fotoğraf ağırlıklı olarak görsel içerikler paylaştığı ve bazı günlerde link paylaşımında bulunduğu görülmektedir. 
Bu durum kullanıcı alışkanlıklarını da gündeme getirmektedir. Yani farklı içerikleri talep eden farklı kesimden, yaştan kitlelerin çevrimiçi ağlarda bulunduğunu belirten pek çok araştırmaya ek olarak habercilik açısından bakıldığında haberin güvenirliği, takipçi sayısı ve yorumları gibi pek çok durumlara yönelik kullanıcı tutumları da devreye girmektedir. Tutgun-Ünal'a göre (2020a, s. 17), sosyal medya topluluk oluşturma ve etkileme gücünün en çok kullanıldığı etkileşimli ortamlardır. Bu yönüyle sosyal medya gazeteciliğinin pek çok dinamik açısından sorgulanmaya ihtiyacı vardır. Örneğin; paylaşılan içerikten ziyade popülerlik de ön planda olabilmektedir.

Instagram ve YouTube gibi fotoğraf/video paylaşımlarının ağırlıklı olduğu sosyal medya uygulamalarında İhlas Haber Ajansının konumu dikkat çekmektedir. Yapılan incelemelerde, YouTube takipçi sayısı en fazla olan İhlas Haber Ajansının diğer haber ajanslarının iki katı takipçi sayısına sahip olduğu ortaya çıkmıştır. Diğer yandan, Instagram takipçi sayısının en yüksek olduğu görülen Anadolu Ajansının belirli bir takipçi kitlesine ulaştığı diğer sosyal medya hesaplarındaki takipçi sayıları da dikkate alındığında söylenebilir. Instagram'da takipçi sayısı açısından ikinci sırada İhlas Haber Ajansının geldiği, üçüncü sırada gelen Demirören Haber Ajansının ise haftalık takipçi artış oranının en yüksek olduğu görülmüștür. Haftalık artıș oranının yüksek olması ilerleyen zamanda takipçi sayılarının yükseliş göstereceği hakkında fikir vermektedir.

Yine Demirören Haber Ajansının Youtube kanalında abone sayısı açısından üçüncü sırada gelmesine rağmen haftalık takipçi artış oranının diğerlerinden neredeyse iki kat fazla olması ilerleyen zamanda sıralamaların değișebileceğini işaret etmektedir.

Tutgun-Ünal ve Deniz'e göre (2020), Z Kuşağının yaşça büyük bir kısmı lise öğrencilerinden oluşurken bir kısmı da henüz ilköğretime başlamamış çocukları kapsamaktadır. Bu bağlamda yaptıkları araştırmada lise öğrencilerini kapsayan Z kuşağının Instagram ve Youtube kullanım oranlarının yüksek bulunması genç kuşaklara hitap etmede haber ajanslarının Youtube kanallarını tercih edebileceklerini göstermektedir. Diğer taraftan, Tutgun-Ünal ve Deniz'in (2020) yaptığı sosyal medya kuşakları araștırmasında $\mathrm{X}$ ve Baby Boomer kuşaklarının birinci sırada Facebook'u kullandığı ve özellikle X kuşağının \%70,6'sının, Y kuşağının ise \%64,5'inin güncel haber içeriklerini takip ettiği ortaya çıkmıştır. Hatta 1946 ile 1964 yılları arasında doğan Baby Boomer kuşağının yarıdan fazlası Facebook'tan güncel haberleri takip ettiğinin bulunduğu araștırma çevrimiçi kullanıcılara hitap etmek isteyen haber ajanslarının Facebook'tan haber yayabileceklerini göstermiştir.

Araştırmada da ülkemizde önde gelen haber ajanslarının Facebook haberciliği yaptıkları görülse de açık ara farkla Anadolu Ajansının birinci sırada yer aldığı ve Facebook'tan güncel haber takibi yapan kuşaklara hitap ettiği söylenebilir. Fakat araștırma kapsamında incelenen bir haftalık dönemdeki verilere göre haftalık takipçi oranında tek pozitif artışın Demirören Haber Ajansında görülmesi sosyal medya ölçümünün önemsendiğini göstermiştir.

Haber ajanslarının Facebook abone sayıları yüksek bile olsa haftalık artış oranlarının eksiye düştügü de gözlenmektedir. Bu da artık Facebook yerine özelilkle genç kuşaklar tarafından birinci sırada tercih edilen Instagram ve YouTube haberciliğinin daha fazla önemsendiği konusunda ipucu sağlamaktadır. Diğer yandan Twitter Gazeteciliğinin ise halen güncelliğini koruduğu pozitif yöndeki performans artışları göz önüne alındığında söylenebilir. 
Sosyal medya gazeteciliğinde her zaman birden fazla sosyal medya platformunda bulunarak bu platformlardan özel, yerel içerik yayınlamak yeni bir standart olarak belirtilmektedir (Rashidian ve diğ., 2018, s. 252). Haber ajanslarının sosyal medya hesapları incelendiğinde pek çok farklı platformdan haber yayını yaptıkları ve sosyal medya yönetimi ile performanslarını takip ettikleri görülmektedir. Her yaştan kullanıcının haber içeriklerine erişmek için farklı sosyal medya uygulamalarını sıklıkla tercih etmesi durumunun kuşak araştırmalarında da bildirilmesi gazetecilik alanını da etkilemiştir. Böylece bağlantılılık özelliği ile aynı anda birçok platformdan haberin paylaşılması sosyal medya gazeteciliği için gereklilik haline gelmiştir.

Görüldüğü gibi yeni medya ile yaygınlaşan etkileşimli web ortamlarından biri olan sosyal medya platformları hem görsel özellikleri ön planda tutarak hem de sosyal etkileşime imkan sağlayarak yoğun kullanıcı kitlesini bünyesine almış olup pek çok alandaki iş yapma şekillerine yeniliklikler getirmiş, haberciliğe de görsel bir bakış açısı getirerek geleneksel gazetecilik ve hatta internet gazeteciliğini dönüştürmüştür. Böylece, gerek vatandaşların gerekse haber ajanslarının yaptığı haberleri sosyal medya ağlarından paylașmaya devam edeceği günümüzde yapılacak yeni araştırmalar ile sosyal medya gazeteciliğinin geleceği takip edilebilir.

\section{Kaynakça}

Akyazl, E. ve Tutgun-Ünal, A. (2013). İletişim fakültesi öğrencilerinin amaç, benimseme, yalnızlık düzeyi ilişkisi bağlamında sosyal ağları kullanımı. Global Media Journal TR, $3(6), 1-24$.

Atalay, G. E. (2020). Yeni medya ve alternatif gazetecilik: Yeni olanaklar, sorunlar ve tartışmalar. Hiperyayın, 1 Basım: İstanbul.

Boomsocial (2019). Sosyal Medya Ölçümleme \& Analiz. Erişim adresi: https://www. boomsocial.com/

Borges-Rey, E. (2015) News Images on Instagram, Digital Journalism, 3:4, 571-593. doi: $10.1080 / 21670811.2015 .1034526$

Civic Impact of Journalism Project (2017). Civic impact of journalism Project. University of Melbourne. Erişim adresi: https://arts.unimelb.edu.au/caj/research/researchprojects/the-civic-impact-of-journalism

Christakis, N. A. ve Fowler, J.H. (2012). Sosyal ağların şaşırtıcı gücü ve yaşantımızı biçimlendiren etkisi. Varlık Yayınları: İstanbul.

Ekşili, N. ve Antalyalı, Ö.L. (2017). Türkiye'de Y kuşağı özelliklerini belirlemeye yönelik bir çalışma: Okul yöneticileri üzerine bir araştırma. Humanities Sciences (NWSAHS), 12(3):90-111. doi: 10.12739/NWSA.2017.12.3.4C0219

Habermas, J. (1989). The structural transformation of the public sphere. Cambridge: Polity Press.

Harcup, T. ve O'Neill, D. (2017). What is news? News values revisited (again). Journalism Studies, 18 (12), 1470-88.

İrvan, S. (2014). İnternet gazeteciliğinde fırsatlar ve tehditler. Yeni Düzen. Erişim adresi: http://www.yeniduzen.com/internet-gazeteciliginde-firsatlar-ve-tehditler2981yy.htm 
Karasar, N. (2018). Bilimsel Araștırma yöntemi. (33. Bsm.) Nobel Akademik Yayıncılık: Ankara.

Kıyan, Z. ve Törenli, N. (2018). Sosyal medyanın gazetecilikteki rolü: Türkiye'deki haber kuruluşları üzerine bir inceleme. Gaziantep University Journal of Social Sciences, 17 (1), 32-52.

Kwak, H., Lee, C., Park, H. ve Moon, S. (2010). What is Twitter, a social network or a news media? Proceedings of the 19th International Conference on World Wide Web, 591-600. Erişim adresi: http://www.ambuehler.ethz.ch/CDstore/www2010/ www/p591.pdf

Lamble, S. (2011). News as it happens: An introduction to journalism. Melbourne: Oxford University Press.

Larsson, A. O. (2017). The news user on social media: A comparative study of interacting with media organizations on Facebook and Instagram. Journalism Studies, 19 (15), 2225-2242. doi: 10.1080/1461670X.2017.1332957

Lasica, J.D. (2003). Blogs and journalism need each other. NiemanReports, 57(3), 70-4.

Lasorsa, D. L., Lewis, S. C. ve Holton, A. E. (2012). Normalizing Twitter: Journalism practice in an emerging communication space. Journalism Studies, 13(1), 19-36. doi:10.108 0/1461670X.2011.571825.

Lippmann, W. (1920). Liberty and the News. Princeton: Princeton University Press.

Maares, P. ve Hanusch, F. (2018). Exploring the boundaries of journalism: Instagram micro-bloggers in the twilight zone of lifestyle Journalism. Journalism, Advance online publication. doi:10.1177/1464884918801400

Marwick, A.E. (2018). Why do people share fake news? A sociotechnical model of media effects. Georgetown Law Technical Review, 2, 474 - 512.

McNair, B. (2005). What is journalism? in H. de Burgh (ed.), Making Journalists: Diverse Models, Global issues Routledge London, 25-43.

McQuail, D. (2000). McQuail's Mass Communication Theory. SAGE Publications.

Medium (2018). The ethical issue of social media in Journalism. Erişim adresi: https:// medium.com/@ryan.guerrero/the-ethical-issues-of-social-media-in-journalism430c85ca8fd1

Nechushtai, E. ve Lewis, S.C. (2018). What kind of news gatekeepers do we want machines to be? Filter bubbles, fragmentation, and the normative dimensions of algorithmic recommendations. Computers in Human Behavior, Erişim adresi: https://www. sciencedirect.com/science/article/pii/S0747563218303650?via\%3Dihub

Özdemir, Ş. (2017). Kuşaklar teorisine göre Türkiye'deki gençlerin medya kullanım alışkanlıkları ve İstanbul örneği, Yüksek Lisans Tezi, Marmara Üniversitesi Sosyal Bilimler Enstitüsü, İstanbul.

Park, S., Fisher, C., Fuller, G. ve Lee, J.Y. (2018). Digital news report: Australia 2018. News and Media Research Centre, University of Canberra.

Rashidian, N., Brown, P., Hansen, E., Bell, E., Albright, J. ve Hartstone, A. (2018). Friend and Foe: The platform press at the heart of Journalism. Tow Center for Digital Journalism, Columbia University. 
Singer, J.B., Hermida, A., Domingo, D., Heinonen, A., Paulussen, S., Quandt, T., Reich, Z. ve Vujnovic, M. (2011). Participatory journalism: Guarding open gates at online newspapers. Wiley-Blackwell, West Sussex.

Tarhan, N. ve Nurmedov, S. (2019). Bağımlılık, Sanal veya Gerçek Bağımlılıkla Başa Çıkma, Timaş Yayınları, 7. Baskı, İstanbul.

Turgut, S. (2013). Yeni medya. İstanbul: Destek Yayınları.

Tutgun-Ünal, A. (2013). Nesiller ayrılıyor: X, Y veZ nesilleri, Açıkbilim. Erişim adresi: http:// www.acikbilim.com/2013/09/ dosyalar /nesiller-ayriliyor-x-y-ve-z-nesilleri.html

Tutgun-Ünal, A. (2015). Sosyal medya bağımlılı̆̆ı: Üniversite öğrencileri üzerine bir araştırma. Doktora Tezi. Marmara Üniversitesi, İstanbul.

Tutgun-Ünal, A (2019a). İletişim Fakültesi öğrencilerinin sosyal medya bağımlılığının incelenmesi: Üsküdar Üniversitesi örneği. Kastamonu İletişim Araştırmaları Dergisi, $2,49-80$.

Tutgun-Ünal, A. (2019b). Yeni medyada yeni gazetecilik anlayıșı geçerli. Erișim adresi: https://haberuskudar.com/yeni-medyada-yeni-gazetecilik-anlayisi-gecerli

Tutgun-Ünal, A. (2020a). Sosyal medya: Etkileri-bağımlılığı-ölçülmesi. 1. Baskı, Der Yayınları: İstanbul.

Tutgun-Ünal, A. (2020b). Sosyal medya gazeteciliği, içinde Atalay, G.E. (Ed.) Yeni medya ve alternatif gazetecilik: Yeni olanaklar, sorunlar ve tartışmalar, hiperyayın, İstanbul, 43-90.

Tutgun-Ünal, A. ve Deniz, L. (2019). Sosyal medya kuşaklarının sosyal medya kullanım seviyeleri ve tercihleri. 5. Uluslararası Sosyal ve Eğitim Bilimleri Araștırmaları Kongresi, Bandirma.

Tutgun-Ünal, A. ve Deniz, L. (2020). Sosyal medya kuşaklarının sosyal medya kullanım seviyeleri ve tercihleri. OPUS-Uluslararası Toplum Araştırmaları Dergisi, 15 (22), 125-144.

Tutgun-Ünal, A. ve Katmer-Bayraklı, V. (2014). Öğretmen adaylarının sosyal medyanın eğitimde iletişim amaçlı kullanılmasına ilişkin görüşleri: Twitter örneği. Uluslararası 1. Avrasya Ĕgitim Araştırmaları Kongresi (EJER), İstanbul.

Türkiye İstatistik Kurumu (2017). Ulaştırma ve haberleşme araştırması. Erişim adresi: http://www.tuik.gov.tr/PreTablo.do?alt_id=1028

Vis, F. (2013). Twitter as a reporting tool for breaking news: Journalists tweeting the 2011 UK riots. Digital Journalism, 1(1), 27-47. doi:10.1080/21670811.2012.741316

Wilding, D., Fray, P., Molitorisz, S. ve McKewon, E. (2018). The impact of digital platforms on news and journalistic content, Australia: University of Technology Sydney. 


\title{
New Journalism Approach via New Media: Analysis of News Agencies in terms of Social Media Journalism
}

\author{
Aylin Tutgun-Ünal (Asst. Prof. Dr.)
}

\section{Extended Abstract}

Social media platforms are the most widespread of the interactive web 2.0 technologies that emerged with New Media, so they are used worldwide with the various features they offer. Initially, the social networks were used for fun and socialization, but nowadays, they are used professionally in many sectors. On the social media platforms used individually as well as institutionally people can introduce themselves or their products globally; they can reach many hard-to-reach people like politicians, artists, or actors.

As social media platforms can be reached via cell phones quickly and cheaply, people of all ages use online social networks. According to Akyazı and Tutgun-Ünal (2013), today, the dominant culture is the participatory culture, and it manifests itself in social networks. Individuals are called users on social networks, and users of all ages create content on social networks, disseminating information. This way, the concept of consumers got transformed alongside digital networks. For instance, previously, newsmakers had a dominant role also in news distribution, but now, this has disappeared as the makers, consumers, and the distributers of social media content can be the same people.

Today, the face of journalism has changed as the first source of news became social media; citizens, news agencies, politicians, and people from various occupations often broadcast news from their social media accounts. Citizens spread the news from various social media accounts as if they were journalists. It can be observed that a multi-dimensional information flow spreads online, especially when the inherent features of the social media such as texts, photos, and videos are connected with other connectivity features like a hashtag (\#), mention (@) and location in this type of journalism.

Previously, the novelties and advantages brought by internet journalism as opposed to the features of traditional journalism were debated (İrvan, 2014). Social media journalism started to be discussed as digital journalism merged with increasingly popular social networks and their unique features. Thus, news agencies enrolled in social media measurement sites to track their performance and shared daily news on their social media accounts, which heralded a new era in journalism.

On the other hand, each of the social media applications has some distinctive features. When Twitter first appeared, texting was its distinctive feature, restricted to max. 140 characters. Later, social media applications became more and more visual, especially with the intensive use by young people of Generation Y (born between 1979-1999) and Generation Z (born between 2000 and later). According to research on social media generations, it is found that Generations $\mathrm{Y}$ and $\mathrm{Z}$ primarily use Instagram (Tutgun-Ünal and Deniz, 2019, 2020). Also, Generation Z's frequency of YouTube use is found to be close to-i.e., high - that of Instagram. Data from research on social media use among different age groups draw a road map for social media journalism.

As every social media application is used intensely by different age groups for different purposes, this now requires citizens to be intent on journalism as well as professionals to 
be present in all these media at the same time in order to disseminate news. It is possible to share the same post on various platforms simultaneously through this connectivity feature. For example, the Story feature on Facebook and Instagram works in an integrated format.

Therefore, it is predicted that the new social media types of journalism, such as Twitter journalism, Instagram journalism, YouTube journalism, and even more specifically, Story journalism will become more widespread and meet the information needs of the online social media public.

When we review the literature, we present different articles about social media journalism (Borges-Rey, 2015; Maares and Hanusch, 2018; Wilding et al., 2018). In a study using the term 'Instagram journalism,' Instagram posts by professional photographers, as well as those by amateur photographers, were examined according to the dynamics of journalism (Borges-Rey, 2015). In another study, the discourse used in Instagram posts were studied structurally; and some similarities were observed with the vocational ideologies of journalism (Maares and Hanusch, 2018).

Thus, it is understood that "social media journalism" that takes place in the social media environment and covers all online users appeals to a broader audience. At this point, it is imperative to know the status of the news agencies, which are responsible for providing news to large audiences in terms of social media journalism, since nowadays news control is done from social media networks. From this point of view, it was aimed at this research to examine news agencies in terms of social media journalism. For this purpose, social media activities of the famous three news agencies in Turkey were investigated via "Boomsocial", the social media measurement website. In the research carried out according to the general survey model, news agencies' number of followers, weekly follower growth rates, number of shared messages, and message types were compared in a one-week period of March 2020.

As a result of the research, the attitudes of news agencies towards social media journalism were tried to be determined in line with the number of followers, the number of messages, types of messages, and weekly follower growth rates in social media applications. According to the data obtained, it turned out that news agencies give importance to social media measurement. In the study, the difference in the weekly follower growth rates showed that the number of followers would affect the increase in the coming period, and the rankings may change.

It is thought that the future status of social media journalism, which is becoming widespread, can be determined by this new type of research.

Keywords: Journalism, New Media, Social Media, Social Media Journalism. 